\title{
Meningkatkan Kemampuan Berbicara Melalui Metode Bercakap-cakap Berbantuan Media Audio Visual Pada Kelompok A PAUD Pertiwi I Kota Bengkulu
}

\author{
Mutiara Purnama Sari \\ mutiarapurnamasari941@gmail.com \\ Sri Saparahayuningsih \\ saparahayuningsih@unib.ac.id \\ Indrawati \\ tindrawati61@gmail.com
}

\begin{abstract}
This research was aimed at improving speaking ability through conversation method via audio visual media. This research is a classroom action research that was conducted in two cycles with three meetings in every cycle. The subjects of this research were group $A$ children consisting of 11 people where there were 5 males and 6 females. For collecting the data, researcher using observation technique was done through observation, while the data analysis was using statistical formula of percentage and mean test. The result of this research proved that through audio-visual media, it can improve the speaking ability. The average of children speaking ability in cycle I has enough criteria, while in cycle II the criteria of children speaking ability was good. From the result of this research, it is suggested for the further researcher to study with the big book and hand puppet media, because with the audio visual media, some children still difficult to utter sounds of language and clarify verbalism
\end{abstract}

Keywords: Speaking Ability; Conversation Method; Audio Visual Media

\section{PENDAHULUAN}

Penelitian ini dilatar belakangi oleh adanya permasalahan di PAUD Pertiwi I Kota Bengkulu, yakni anak belum mampu berbicara dengan baik, rata-rata kemampuan berbicara anak masih kurang baik dari aspek pelafalan, pemilihan kata (kosakata), struktur kalimat, sikap yang wajar, gerak gerik dan mimik, serta kelancaran. Oleh karena itu, peneliti ingin memperbaiki kemampuan berbicara anak dengan metode bercakap-cakap berbantuan media audio visual.

Rumusan masalah dalam penelitian ini adalah bagaimana meningkatkan kemampuan berbicara melalui metode bercakap-cakap berbantuan media audio visual pada kelompok A PAUD Pertiwi I Kota Bengkulu?.

Hurlock (1978: 176) mengemukakan bahwa berbicara adalah bentuk bahasa yang menggunakan artikulasi atau kata-kata yang digunakan untuk menyampaikan maksud. Sejalan dengan itu, Tarigan (2008:16) mengungkapkan bahwa kemampuan berbicara adalah mengucapkan bunyi-bunyi artikulasi atau kata-kata untuk mengekspresikan, menyatakan, serta menyampaikan pikiran, gagasan dan perasaan. Selanjutnya Dhieni (2011:1.19) kemampuan berbicara merupakan suatu ungkapan dalam bentuk 
kata-kata.Kemampuan berbicara mengacu kepada beberapa faktor pendukung yang harus diperhatikan untuk menunjang keefektivitasan kemampuan berbicara, yaitu faktor kebahasaan (pelafalan, pemilihan kata, struktur kalimat) dan faktor nonkebahasaan (sikap yang wajar, gerak gerik dan mimik, kelancaran) Arsjad dan Mukti (dalam Zakaria, 2017: 9-20).

Metode bercakap-bercakap adalah komunikasi lisan antara anak dan guru atau antara anak dengan anak melalui kegiatan monolog dan dialog (Moeslinghatoen, 2004:92).

Menurut Wati (2016: 5) media audio visual adalah media yang dapat menampilkan unsure gambar dan suara secara bersamaan pada saat mengkomunikasikan pesan atau informasi.

\section{METODE PENELITIAN}

Jenis penelitian yang digunakan dalam penelitian ini adalah Penelitian Tindakan Kelas (Classroom Action Research) yang terdiri dari 4 tahap yang dilakukan yaitu: 1 ) perencanaan, 2) tindakan, 3) pengamatan, dan 4) refleksi (Arikunto, 2010: 5).

Teknik pengumpulan data dalam penelitian ini menggunakan teknik observasi. Observasi dalam penelitian ini berisi aspek-aspek yang berkaitan dengan hal-hal yang akan diobservasi yakni dari aspek pelafalan, pemilihan kata, struktur kalimat, sikap yang wajar, gerak gerik dan mimik, kelancaran.

Penelitian ini hanya menggunakan satu instrumen yaitu lembar observasi. Lembar observasi yang digunakan dalam penelitian ini adalah lembar observasi aktivitas guru dan lembar observasi kemampuan anak dalam berbicara melalui metode bercakap-cakap berbantuan media audio visual.

Adapun analisis data menggunakan nilai uji rata-rata dan ketuntasan belajar untuk mengetahui peningkatan kemampuan berbicara anak melalui metode bercakap-cakap berbantuan media audio visual. Dalam penelitian ini dapat dikatakan berhasil apabila kemampuan berbicara anak mencapai ketuntasan 75 \% (Aqib, 2009: 4041).

\section{HASIL DAN PEMBAHASAN}

Berdasarkan hasil observasi kemampuan berbicara anak mengalami peningkatan yang baik. Hal ini terlihat dari siklus I pertemuan ketiga dengan nilai ratarata 3,52 dengan kriteria cukup dengan ketuntasan belajar 45,45 \%. Kemudian meningkat pada siklus II pertemuan ketiga yang mencapai rata-rata 4,14 dengan kriteria baik dan ketuntasan belajar 81,81 $\%$.

Sebelum perlakuan rata-rata kemampuan berbicara anak kurang. Kemudian setelah perlakuan dari siklus I kemampuan berbicara anak cukup dan pada perlakuan siklus II kemampuan berbicara anak menjadi baik.

Adapun media yang digunakan untuk meningkatkan kemampuan berbicara anak yaitu video yang berupa gambar dan suara (audio visual) dan metode yang digunakan adalah metode bercakap-cakap. Kegiatan bercakap-cakap berbantuan media audio visual (video) mampu memotivasi dan menumbuhkan semangat anak untuk aktif dalam kegiatan pembelajaran.

Adapun teori yang mendukung yaitu menurut Hurlock (dalam Susanto, 2017: 158) menyebutkan bahwa untuk memperbaiki kemampuan berbicara anak berasal dari empat sumber, yaitu orang tua dan lingkungan sekitarnya yang dapat memacu bicara anak dengan lebih baik dengan cara mengajak anak untuk berbicara (bercakap-cakap) dan memperbaiki salah ucap dan tata bahasa, media yang digunakan (radio, video, dan televisi) yang mendorong anak untuk mengerti yang dikatakan oleh orang lain, setelah anak belajar membaca maka anak akan terbiasa menambah kosakata dan mengucapkan bentuk kalimat yang benar setelah anak mulai sekolah, kemampuan 
berbicara diantaranya adalah sejumlah pembendaharaan kata, struktur kalimat dan pelafalan.

Sedangakan menurut Arsjad dan Mukti (dalam Zakaria, 2017: 20) yang mendukung kemampuan berbicara anak baik dari aspek pelafalan, pemilihan kata (kosakata), struktur kalimat, sikap yang wajar, gerak gerik dan mimik, serta kelancaran. Sejalan dengan itu, Arsyad (2011: 49-50) mengemukakan bahwa kelebihan media audio visual yaitu mendorong dan meningkatkan motivasi dan menanamkan sikap-sikap dari segi afektif, dapat memberikan pengalaman dasarjiwa, mampu mengatasi keterbatasan waktu, ruang,kemampuan daya indera manusia, suara yang diperdengarkan dapat memberikan latihan pada anak, dapat memperlihatkan suatu proses secara tepat, dan memperlihatkan berbagai macam warna, animasi, gerakan dan sebagainya.

Sedangakan Moeslinghatoen (2004: 95) menyatakan pendapat metode bercakap-cakap bagi anak yaitu, meningkatkan keberanian anak untuk mengaktualisasikan diri dengan bahasa ekspresif untuk menyatakan pendapat, perasaan, dan meyakinkan kebutuhan secara lisan, meningkatkan keberanian anak untuk mengadakan hubungan dengan orang lain untuk menciptakan interaksi yang menyenangkan, dan meningkatkan keberanian anak berbicara untuk menyatakan keinginannya dan dapat kesempatan untuk mengemukakan pendapatnya, serta meningkatkan keterampilan berkomunikasi dengan orang lain.

Berdasarkan hasil observasi siklus I dan siklus II, maka diperoleh hasil peningkatan kemampuan berbicara yang sedemikian rupa dari indicator yang ditetapkan. Dengan demikian dapat dikatakan bahwa melalui kegiatan bercakap-cakap berbantuan media audio visual dapat meningkatkan kemampuan berbicara anak kelompok A PAUD Pertiwi I Kota Bengkulu.

\section{PENUTUP}

Simpulan

Dari hasil penelitian dapat disimpulkan bahwa kemampuan berbicara anak meningkat dengan media audio visual. Media audio visual mudah bagi anak untuk mendengarkan dan memahami kata-kata yang ada dalam video. Karena media audio visual menarik sehingga anak tertarik untuk mrndengarkan dan memperhatikan cerita yang disampaikan oleh guru.

\section{Saran}

Saran bagi peneliti selanjutnya untuk dapat melanjutkan penelitian tentang kemampuan berbicara anak menggunakan media lain seperti media big book dan hand puppet.

Saran bagi guru untuk dapat menggunakan media audio visual dalam meningkatkan kemampuan berbicara anak dengan memperhatikan konsep media dan video yang ditampilkan harus bervariasi pada setiap pertemuan. Hal ini dapat memberikan pengalaman dan pengetahuan yang lebih banyak kepada anak.

\section{DAFTAR PUSTAKA}

Aqib, Zainal, dkk. (2009). Penelitian Tindakan Kelas untuk Guru SD, SLB, $T K$. Bandung: CV. Yrama Widya.

Arikunto, Suharsimi, dkk. (2010). Penelitian Tindakan Kelas. Jakarta: Bumi Aksara.

Arsyad, Azhar. (2011). Media Pembelajaran. Jakarta: PT Raja Grafindo Persada.

Dhieni, Nurbiana, dkk. (2011). Metode Pengembangan Bahasa. Jakarta: Universitas Terbuka.

Hurlock, Elizabeth B. (1978). Perkembangan Anak Jilid 1. Jakarta: PT Gelora Aksara. 
Moeslinghatoen R. (2004). Metode Pengajaran di Taman Kanak-kanak. Jakarta: PT Rineka Cipta.

Rima, Wati. (2016). Ragam Media Pembelajaran. Jakarta: Kata Pena.

Susanto, Ahmad. (2017). Pendidikan Anak Usia Dini Konsep dan Teori. Jakarta: PT Bumi Aksara.

Tarigan, Henry Guntur. (2008). Teknik Pengajaran Keterampilan Berbahasa. Bandung: Bumi Aksara.

Zakaria, Jelita. (2017). Bahan Ajar Keterampilan Berbicara. Universitas Muhammadiyah Bengkulu 